\title{
THE PROFITABILITY ANALYSIS ON BASE THE PROFIT AND LOSSES ACCOUNT WITHIN THE AGRICULTURAL HOLDINGS
}

\author{
Professor PhD Vasile Burja \\ „1 Decembrie 1918” University Alba Iulia, Romania
}

\begin{abstract}
The profit and losses account constitutes the principal instrument for appreciating the profitability of agricultural holdings. Data offered by this instrument have to be processed with means of economic-financial analysis in order to quantify the real extend of the economic performance, its tendency, influence factors and existence of internal reserves. The paper presents some possibilities to analyze the holdings profitability using the profit and losses account illustrated in an adequate case study.
\end{abstract}

The losses and profit account in an account document of synthesis which according to the Account Law each enterprise has the obligation to fill it out annually with the other financial situations. It offers a devoted image of the financial performance of the enterprise synthesizing in an explicit manner the earnings and the expenditures from an administrative period and on this base it presents the development of the economic results.

In its essence the profit and losses account contains:

- earnings realized during the financial exercise

- expenditures made in that exercise

- outcomes during the same period

Nowadays, according to the EU Directives, there is no universal scheme to present the profit and losses account. Practically there have been identified four schemes, the difference between these being the emplacement rules of the elements inside each one:

- $\quad$ By the way it is presented, the account and profit losses can be achieved:

- the bilateral form (account type), expenditures and losses being passed in the left side, while incomes and profits in the right.

- the vertical format (list type) which explains the gradual formation of the exercise's result.

- By the criterion taken into consideration in structuring expenditures and incomes, the profit and losses account can be achieved by:

-the nature of expenditures and incomes (the Romanian and France practice)

-by the function (destination) of the expenditures and incomes (the Anglo-Saxon practice).

The Account Law foresees for the enterprises in our country the making of the losses and profit account under the list format and the expenditures and incomes are presented through their nature. At a commercial agricultural holding organized under the form of a Ltd. the profit and losses account is presented in table 1:

Table 1

The profit and losses account (thousand Ron)

\begin{tabular}{|l|c|c|c|c|}
\hline \multirow{2}{*}{ Indicators } & \multicolumn{4}{c|}{ Period } \\
\cline { 2 - 5 } & $\mathbf{2 0 0 3}$ & $\mathbf{2 0 0 4}$ & $\mathbf{2 0 0 5}$ & $\mathbf{2 0 0 6}$ \\
\hline Incomes from operating activity & 25420 & 40017 & 53471 & 71543 \\
Expenditures from operating activity & 22464 & 36112 & 44793 & 62697 \\
\hline The result from operating & 2956 & 3905 & 8678 & 8846 \\
\hline Financial incomes & 42 & 40 & 10 & 42 \\
Financial expenditures & 885 & 1966 & 2189 & 2659 \\
\hline
\end{tabular}




\begin{tabular}{|l|c|c|c|c|}
\hline The financial result & -843 & -1926 & -2179 & -2617 \\
\hline Extraordinary incomes & 211 & 0 & 0 & 0 \\
Extraordinary expenditures & 780 & 0 & 0 & 0 \\
\hline The extraordinary result & -569 & 0 & 0 & 0 \\
\hline The current result & 2113 & 1979 & 6499 & 6229 \\
\hline The gross result of the exercise & 1544 & 1979 & 6499 & 6229 \\
\hline The net result of the exercise & 1158 & 1484 & 5524 & 5232 \\
\hline
\end{tabular}

We observe the spectacular activity of the analyzed agricultural holding, which during the respective time period has tripled its activity volume, aspect reflected by the dynamic of the incomes and expenditures from exploitation.

The profit and losses account allows for an overall analysis of the enterprise's profitableness. We get the first image regarding this trough the dynamic and analysis of the result indicators. For the agricultural exploitation analyzed in this case of study its evolution is presented in grill no. 2:

The results' dynamic, thousands Ron

\begin{tabular}{|l|c|c|c|c|}
\hline \multirow{2}{*}{ Specification } & \multicolumn{4}{c|}{ Period } \\
\cline { 2 - 5 } & $\mathbf{2 0 0 3}$ & $\mathbf{2 0 0 4}$ & $\mathbf{2 0 0 5}$ & $\mathbf{2 0 0 6}$ \\
\hline 1.The result of operating activity & 2956 & 3905 & 8678 & 8846 \\
- Relative deviation \% & - & 32 & 194 & 199 \\
\hline 2. Financial result & -843 & -1926 & -2179 & -2617 \\
- Relative deviation \%* & - & $128^{*}$ & $158^{*}$ & $210^{*}$ \\
\hline 3. Current result & 2113 & 1979 & 6499 & 6229 \\
- Relative deviation \% & - & -6 & 207 & 194 \\
\hline 4. Extraordinary result & -569 & - & - & - \\
- Relative financial \% & - & & & \\
\hline 5.The gross result of the exercise & 1544 & 1979 & 6499 & 6229 \\
- Relative deviation \% & - & 28 & 321 & 303 \\
\hline 6.The net result of the exercise & 1158 & 1484 & 5524 & 5232 \\
- Relative exercise \% & - & 28 & 377 & 352 \\
\hline
\end{tabular}

* increase compare to the negative base

Table 2

The growth of the exercise's result can be seen from the dates in table 2, comparing the last three years to 2003. This is owned to the growth of the result from exploitation. In the year 2006 there has been obtained a gross result smaller than the one in 2005, even though the exploitation result was clearly superior. The financial result was negative, the distance between the financial expenditures and the financial growing from year to year. The dynamic of the gross result in 2005 was influenced by the decrease in the taxation quota from $25 \%$ to $16 \%$, once with the introduction of the unique taxation quota.

Other information regarding the overall analysis of the profitableness based on the profit and losses account obtained from the weight calculation of each type of result within the gross result of the exercise. Appreciations can be made regarding the contribution of each type of activity (productive, financial, exceptional), regarding the results of the analyzed agricultural society and the degree in which the profitableness growth is owned to the realizing of its base object. The structural indicators of the results are:

- $\quad$ the weight of the operating result (PE) 


$$
P E=\frac{\text { Operating result }}{\text { The gross result of the exercise }} \cdot 100
$$

- $\quad$ the weight of the financial result $(\mathrm{PF})$ :

$$
P F=\frac{\text { Financial result }}{\text { The gross result of the exercise }} \cdot 100
$$

- $\quad$ the weight of extraordinary result (PEX):

$$
P E X=\frac{\text { Extraordinary result }}{\text { The gross result of the exercise }} \cdot 100
$$

It can be identified the positive or negative contribution of each activity (operating, financial, exceptional) in order to form the gross result of the exercise.

Table 3

The weight of results categories within the gross operating result (\%)

\begin{tabular}{|l|c|c|c|c|}
\hline \multirow{2}{*}{\multicolumn{1}{|c|}{ Specifications }} & \multicolumn{4}{c|}{ period } \\
\cline { 2 - 5 } & $\mathbf{2 0 0 3}$ & $\mathbf{2 0 0 4}$ & $\mathbf{2 0 0 5}$ & $\mathbf{2 0 0 6}$ \\
\hline The operating weight result & 191 & 197 & 133 & 142 \\
The financial weight result & -55 & -97 & -33 & -42 \\
The extraordinary weight result & -37 & - & - & - \\
\hline
\end{tabular}

We can see from the dates in table 3 the final contribution in obtaining the profit of the operating result, while the financial result has decreased the positive result obtained from the exploitation , and caused also the decrease of the gross result of the exercise. This situation shows the fact that for the analyzed agricultural holding the main source in obtaining positive economic effects, is the base activity, effects which are negatively influenced by the financial dimension of the society's activity, which is affected by the payment of relatively high rates of the contracted credits. The extraordinary result has influenced the gross result of the exercise in a small matter; the negative influence took place only in 2003, and in the last three years the extraordinary result was null.

Another possibility of completing the whole analysis of the profitableness in the holding, based on the profit and losses account, is the analysis of the profitability based on rates.

These can be calculated as a report of different categories of results and the expenditures or incomes which correspond to them.

Accordingly we have:

- rates of the consumed resources

- rates of the realized incomes

A. The analysis of the ratability based on the rates of the consumed resources defines the efficiency of the activity based on the report effect/effort.

The following rates can be calculated and analyzed:

a.1. The rate of the profitability of the consumed resources (RPRC) shows the gross profit realized with one unit of total expenditures (or 100 units if it is defined in percentage) and therefore measures the capacity of the consumed resources in generating gross profit. It can be calculated as bellow: 


$$
R P R C=\frac{\text { The gross result of the exercise }}{\text { Total } \text { exp enditures }} \times 100
$$

The increase of the rate during the exploitation period, shows a positive situation for holding, and it takes place when the index of the gross result of the exercise overcomes the index of the increase of total expenditures.

a.2. The rate of profitability of current resources (RPCC) shows the profitability of consumed resources in the current activity (operating and financial) and it can be calculated as shown bellow:

$$
\text { RPCC }=\frac{\text { Current result }}{\text { Current } \text { expenditures }} \times 100
$$

This rate eliminates the influence of the extraordinary result over the gross result of the exercise, which means the efficiency of the activity performed currently. The increase in the dynamics of the rate has the same signification as at the previous rate, and the internal funds of increasing the profitability expressed by this rate are also common to the previous ones.

a.3. The rate of profitability of the resources consumed in exploitation (RPCE) show the profitability of the exploitation activity and is relevant especially in the situation when the financial and the extraordinary activity is highly influenced by the gross result of the exercise.

It can be calculated as shown bellow:

$$
R P C E=\frac{\text { The operating result }}{\text { The expenditure result }} \times 100
$$

The increasing dynamic of the rate also expresses a positive situation for the operating activity of the holding and the internal funds for the increase of this activity are used for the increase of the operating incomes, faster than the operating expenditures, which means in fact the decrease of the expenditures as the income unit.

B. The analysis of the profitability based on the realized incomes shows economic efficiency throw the report effect/effect and can express the capacity of incomes to generate profit. For this the following rates must be used:

b.1. The rate of the profitability of the total incomes (RPVT) shows the weight of the gross result of the exercise in the total income and reflects the global efficiency of the activity. It can be calculated as shown bellow:

$$
R P V T=\frac{\text { The brutto result of the exercise }}{\text { Total incomes }} \times 100
$$

The dynamic growth of the rate shows a positive situation and can be obtained by increasing the gross result of the exercise in a faster way than the increase of the total incomes, which actually means the decrease of the expenditure on the income unit. Therefore it results that the profitability rate of the total incomes is complementary to the profitability rate of the consumed resources.

b.2. The rate of the profitability of current incomes (RPVC) reflects the efficiency of the activity of exploitation and the financial one, eliminating the influence of the extraordinary activity, which sometimes can change the gross result of the exercise.

It can be calculated as a weight of the current result in the current incomes as we can see bellow: 


$$
R P V C=\frac{\text { Current result }}{\text { Current incomes }} \times 100
$$

The increasing dynamic of the rate shows improvement of the exploitation activity and the financial one, from the perspective of the economic efficiency and it can be realized by reducing the exploitation expenditures and the financial ones in parallel to the growth of the incomes realized in that certain activity.

b.3. The rate of the profitability of the incomes from the exploitation (RPVE) shows the profitableness of the main activity of the holding, meaning the activity that constitutes the object of activity. This rate eliminates also the influence of the financial activity, which by the financial expenditures influences in a highly measure the profitability, decreasing the profit. It can be calculated as shown bellow:

$$
R P V E=\frac{\text { Operating result }}{\text { Incomes from operating activity }} \times 100
$$

The internal funds of the growth of the profitableness expressed by this rate can be found among the activities of exploitation and concern the efficiency of this activity, which means a rational usage of the funds corresponding to exploitation, the increase of the physic production, or speeding up the velocity of selling the products.

b.4. The rate of the commercial profitableness (RRC) shows the economic efficiency according to the final state of the economical circuit, therefore it is considered an important pointer in expressing profitableness. It can be calculated as shown bellow:

$$
R R C=\frac{\text { The result of the exercise }}{\text { The turnover }} \times 100
$$

According to the exercise's result we can obtain a gross or a net rate of commercial profitableness.

The internal funds for the increase of profitability expressed by these rates, concern the production activity as well as the selling activity. In order to express this means showed previously regarding the increase of the profitability for the other rates must be completed with measures specific for the marketing and distribution activities.

The situation of the analyzed agricultural holding, expressed by the rates showed previously, can be seen in the table 4:

Table 4

Situation of profitability on base the rates \%

\begin{tabular}{|l|c|c|c|c|}
\hline \multicolumn{1}{|c|}{ Rates } & \multicolumn{4}{c|}{ Period } \\
\cline { 2 - 5 } & $\mathbf{2 0 0 3}$ & $\mathbf{2 0 0 4}$ & $\mathbf{2 0 0 5}$ & $\mathbf{2 0 0 6}$ \\
\hline The profitability rate of the consumed resources & 6,4 & 5,2 & 13,8 & 9,5 \\
\hline The profitability rate of the current resources & 9,0 & 5,2 & 13,8 & 9,5 \\
\hline The profitability rate of the operating resources & 13,2 & 10,8 & 19,4 & 14,1 \\
\hline The profitability rate of the total incomes & 6,0 & 4,9 & 12,2 & 8,7 \\
\hline The profitability rate of the current incomes & 8,3 & 4,9 & 12,2 & 8,7 \\
\hline The profitability rate of the exploitation incomes & 11,6 & 9,8 & 16,2 & 12,4 \\
\hline The rate of commercial profitableness & 3,0 & 1,9 & 8,0 & 6,1 \\
\hline
\end{tabular}


We can see from the dates in table 4 that the profitability expressed by the corresponding rates is positive during the whole period, showing a small decrease in the years 2004 and 2006.

The highest profitability can be found in the exploitation activity, then, especially in the influence of the financial expenditures, and, that of exceptionally ones, which lead to the decrease of the global profitableness, expressed through the profitableness of the consumed resources of the total incomes, and the rate of the net commercial profitableness.

We can also see the rate of the commercial profitability is situated on a low level, which means the usage of the internal funds of the agricultural holding during the whole exploitation cycle, in order to increase the profitableness.

Concerning the dynamic of the rates, we can see that the best results have been obtained in 2005 , and the worst in year 2004, because of the influence of certain external factors, especially the climatic ones, which highly influences production.

\section{Bibliography}

1. Buglea A. - Analiza situației financiare a întreprinderii, Editura Mirton, Timişoara, 2004.

2. Burja C. - Analiză economico-financiară, Editura Risoprint, Cluj Napoca, 2005.

3. Cojocaru C. Constantin - Analiza economico-financiară a exploatațiilor agricole şi silvice, Editura Economică, București, 2000.

4. Cotleț D. Megan O. - Situațiile financiare ale întreprinderii, Editura Orizonturi universitare, Timişoara, 2003.

5. Helfert A. Erich - Tehnici de analiză financiară, Editura BMT Publisjng House, Bucureşti, 2006.

6. Spătaru L. - Analiză economico-financiară, Editura Economică, Bucureşti, 2004. 